\title{
Measuring employee engagement of low-income workers either working at or visiting Marabastad Mall in the City of Tshwane Metropolitan Municipality
}

\author{
Molefe Jonathan Maleka, Cecile Schultz, Lize van Hoek, Leigh-Anne Paul Dachapalli \& Suzette Ragadu \\ Tshwane University of Technology, Pretoria, South Africa \\ Malekam@tut.ac.za,SchultzCM@tut.ac.za,Vanhoekce@tut.ac.za, paulla@tut.ac.za \& ragadusc@tut.ac.za
}

\begin{abstract}
The purpose of this study is to measure employee engagement of low-income workers either working at or visiting Marabastad Mall in the City of Tshwane Metropolitan Municipality (CTMM). The literature review revealed that in the South African context there is a dearth of research on predictors of employee engagement. The research design was a survey and the sample size was six hundred and forty-nine $(\mathrm{n}=649)$. The descriptive statistics show that the respondents were moderately disengaged, disaffected, and committed. The descriptive statistics also revealed that respondents moderately disagreed that they had training opportunities and they had a good quality of work life. The inferential statistics showed that males were more engaged than their female counterparts, part-time employees were slightly more engaged than full-time employees and employees who were unionised were more engaged than the non-union members. It was also found that job satisfaction was the highest predictor of employee engagement $(\beta=0.28, p<0.05)$. The study has implications for policymakers that employees earning between R1 000.00 and R10 000.00 are less engaged and committed and their job satisfaction levels were low. The implication for managers is that they must be aware that development and recognition of employees and job satisfaction predict employee engagement. Quality of work life and labour relations did not predict employee engagement.
\end{abstract}

Keywords: Employee engagement, job satisfaction, organisational commitment, talent management, and quality of work life

\section{Introduction}

Employee engagement is important when a business endeavours to improve its performance and efficiency. It is a broad construct that affects many human resource management (HRM) outcomes. Therefore employee engagement is the one HRM construct that seems to result in employees' ability to perform beyond their employment contract (Markos \& Sridevi, 2010). A Gallup (2013) study showed that 87\% of employees are not engaged in their work. In different studies, researchers indicated that the majority (i.e. 85\%) of employees who were not engaged in their work (Lu, Lu, Gursoy \& Neale, 2016; Karanika-Murray, Duncan, Pontes \& Griffiths, 2015) were also dissatisfied (Chandarot \& Dannet, 2009). It therefore transpired that employees, who are not engaged, end up being paid lower salaries and therefore cannot afford to pay their rent, transport fees to work, and fulfil their basic commitments (Ghosh, Rai \& Chauhan, 2016; Anitha, 2014). In their study, Robyn and Du Preez (2013) pointed out that employees who are not engaged in their jobs seem not to be committed to their work. Viljoen, a prominent HRM scholar in South Africa, found that the relationship between employees and management at ThabaNchu Transport soured because the former were excluded from decision-making (Nienaber \& Martins, 2016). A South African study, conducted in the education sector, comprising mainly high-earning employees, revealed that employee and organisational commitment are related and employees were moderately engaged $(\mathrm{M}=3.78 ; \mathrm{SD}=0.33$ ) (Moshoeu \& Geldenhuys, 2015). A global study showed that $44 \%$ of the respondents rated career development as one of the key drivers of employee engagement (Hewitt, 2015). It can thus be surmised that low organisational commitment, job dissatisfaction, not offering employees training opportunities, and not paying employees well may contribute to their disengagement.

Research on employee engagement has been conducted globally (Olivier \& Page, 2017); however, in the South African context most research on employee/work engagement was based on middle-income earners (Nienaber \& Martins, 2016; Tladinyane \& Van der Merwe, 2016). Therefore, the primary objective of this study is to investigate the predictors of the engagement of low-income employees either working at or visiting Marabastad Mall. The contribution of the study lies in the fact that there is a vast amount of lowincome workers in the South African context. It is essential to determine the predictors of employee engagement of these workers to be able to understand what is important for them to be engaged. With this article, the authors endeavour not only to add to the body of knowledge on lower-income workers in the 
South African context but also to focus managers' attention on the predictors of employee engagement that may advance their competitive edge. With regard to the contribution to the body of knowledge, this paper endeavours to:

- Determine the predictors of employee engagement using linear regression; and

- Collect data from an understudied sample (low-income workers in the South African context) who visited or worked at the Marabastad Mall in the CTMM.

The research objectives of the study were:

- to determine how employees (in terms of gender, union membership, and type of employment) rate employee engagement; and

- to determine which variables, have an effect on employee engagement.

In the next section the theoretical framework will be discussed followed by the methodology, data analysis, conclusion and recommendations.

\section{Literature Review}

In the literature, work -and employee engagement are used interchangeably (Makhoa, 2016). For the purpose of this study, employee engagement is a "positive, fulfilling, work-related state of mind that is characterised by vigour, dedication, and absorption" (Schaufeli, Salanova, González-Romá \& Bakker, 2002, p.71). There are different theories of employee engagement (see Nienaber \& Martins, 2016); however, in this study, the theoretical framework of Schaufeli et al. (2002) was deemed appropriate. The researchers were interested in individual factors (i.e. job satisfaction, talent management, commitment, quality of work life, and co-worker) that predict employee engagement. Schaufeli and Bakker (2003) compared the occupational differences of managers and low-level employees and found that the former were more engaged. This finding is consistent with the research conducted by Nienaber and Martins (2016) in the South African context. However, in our study, we had only one occupational category, hence the interest was in determining which groups (i.e. males or females, unionised or non-unionised, and part-time or full-time) were more engaged. Another research study in South Africa conducted by Janse van Rensburg, Boonzaier and Boonzaier (2013) found that call centre employees had a lower level of engagement. Nienaber and Martins (2016) found that South African males were more engaged than females and union members were more engaged than non-union members. Therefore it is hypothesised that:

H1A: Male employees are more engaged than female employees.

H1B: Union members are more engaged than non-union members.

H1C: Employees employed on a full-time basis are more engaged than employees employed on a part-time basis.

Variables that affect employee engagement: According to Markos \& Sridevi (2010, p.92), most variables that affect employee engagement are not necessarily financial in nature. It can therefore be assumed that a business wanting to improve its level of employee engagement can do so at a lower cost, although the authors warn that financial aspects should not be ignored. These authors noted that the major consequences of disengaged employees includes less productive workforce and employees that miss an average of 3.5 days per year. Engaged employees are willing to show discretionary effort and therefore the following predictors of employee engagement are discussed below: organisational commitment, job satisfaction, quality of worklife, talent management, and employees' relations. One of the variables that affect employee engagement is organisational commitment. Organisational commitment can be defined as the psychological state that determines an employee's relationship with the organisation (Meyer \& Allen, 1991) and willingness to stay in the organisation (Cohen, 2007) because the employee is committed to the organisation's values and ethos (Memari, Mahdieh \& Manani, 2013). The study undertaken by Beukes and Botha (2013) indicated that organisational commitment and employee engagement had a positive correlation $(r=0.42, p<0.01)$. Other research, both in South Africa and internationally, revealed that organisational commitment is a predictor of employee engagement (Albdour \& Altarawneh, 2014; Nienaber \& Martins, 2016; Jackson, Rothmann \& Van de Vijver, 2006) but these studies were not conducted on low-income workers. Based on this discussion, it can be hypothesised that:

H2: Organisational commitment has a positive effect on employee engagement of low-income workers. 
Another human resource variable that has a positive effect on employee engagement is job satisfaction. Job satisfaction is the feeling employees have about their job, co-workers, and the work environment (Locke, 1976). Garg and Kumar (2012) highlighted the meaning of job satisfaction as an important driver of engagement, as their research was focused on certain aspects of working issues such as pay and benefits, customer service values, employment opportunities for advancement, satisfactory working environments in terms of the relations between workers and supervisors, internal communication effectiveness, and reasonable workload. Their findings led them to the conclusion that job satisfaction is a key driver of employee engagement within an organisation. Zikouridis' (2015) study indicated that employee engagement is positively related to job satisfaction $(\mathrm{r}=0.715, \mathrm{p}<0.01)$, which means that high job satisfaction leads to high levels of engagement but low-income workers were not part of this study. It can therefore be hypothesised that:

H3: Job satisfaction positively affects employee engagement of low-income workers.

According to Dessler (1984), quality of work life refers to the degree to which employees in an organisation are able to satisfy important needs through their experience in the organisation. Islam (2012) argued that quality of work life essentially describes an employee's preference in terms of working conditions, remuneration, opportunity for professional development, the role of work-family role balance, safety, and social interaction. Alqarni's (2016) findings showed that quality of work life positively correlated with engagement and that two factors, "development of human capabilities" and "social relevance", were the only significant predictors of engagement. The results of Anitha's (2014) study showed a significant positive relationship between workplace wellbeing and therefore regarded it as a determinant of employee engagement. Galea, Houkes and De Rijk (2014) highlighted the fact that employers are becoming increasingly aware of how critical it is for their businesses to avail work-life balance opportunities for their employees. It can thus be hypothesised that:

H4: Quality of work-life positively affects employee engagement of low-income workers.

Other than the quality of organisational commitment and quality of work life, talent management has been found to affect employee engagement (see Halbesleben, 2010). Mensah (2015) added that talent management is the implementation of integrated strategies designed to increase workplace productivity by developing improved processes for attracting, developing, retaining, and utilising people with the required skills and aptitude to meet current and future business needs. Hughes and Hog (2008) argued that "the benefits of an effectively implemented talent management [...] include improved [...] retention rates, and enhanced employee engagement". Theoretically, it is proposed that training and development management and recruitment and selection (i.e. talent management dimensions) are the antecedents of employee engagement (Albert, Baker, Gruman, Macey \& Saks, 2015). Another study showed that there was a significant positive correlation $(\beta=0.36 ; p<0.05)$ between trained employees who performed well and employee engagement (Halbesleben, 2010). The following hypotheses are therefore brought forward:

H5a: Talent recognition has a positive effect on employee engagement of low-income workers.

H5b: Talent development has a positive effect on employee engagement of low-income workers.

It was noted earlier that union members are more engaged than non-union members. Madlock and BoothButterfield (2012) claimed that employees' relations are important in providing support to co-workers and have a positive effect on employee satisfaction. Employees develop a friendship relationship with co-workers and in some instances are engaged or energised if they are given the opportunity to participate or are given a voice by management (Slabbert, Parker \& Farrel, 2015). Recently in Tshwane, a capital city in South Africa, low-income workers who were not engaged by management as they were not part of unions, embarked on an illegal strike that closed two universities (Makhubu, 2016). Employees who feel a friendship with co-workers experience good mental and physical health (Ariani, 2015). A study undertaken by Ariani (2015) indicated a positive correlation between employee engagement and co-workers' relations. Hence it is hypothesised that: H6: Co-workers relations have a positive a positive effect on employee engagement of low-income workers.

Based on the above discussion, it can be argued that engaging employees is a global issue. The literature shows that the majority of employees are not engaged. It is clear from the literature review that different predictors of employee engagement exist. The research gap here is that it is not clear what the predictors of 
employee engagement of low-income workers are, and this study addresses this gap. Discussed in the next section is the research methodology that the authors followed to address the primary objective mentioned in the introduction.

\section{Methodology}

Discussed in this section are the research design, population and sampling, data collection, questionnaire design, statistical analysis, validity and reliability, and ethical considerations.

Research design: The research design was cross-sectional survey design. The latter assisted the authors to quantify (Leedy \& Ormrod, 2015) the predictors of employee engagement of low-income workers visiting or working at the Marabastad Mall in the CTMM. Since the study design was a survey, the researchers' epistemology was positivism and the researchers' ontological stance was objectivism (Bryman, 2012). This study was also exploratory since similar research has not been conducted before at the Marabastad Mall.

Economic status of respondents: According to Maleka (2017), as well as Carr, Maleka, Meyer, Barry, Parker, and Haar (2017), low-income workers earn between R1 000.00 and R10 000.00 per month. Therefore, employees who earned above R10 000.00 were excluded from the dataset. After excluding the participants earning above R10 000.00, the actual sample size was five hundred and forty-nine $(n=559)$. The present study sample size is above 500, which, according to Leedy \& Ormrod (2016), is a sufficient sample size if the population is more than 5 000.Four research assistants (RAs), conversant with the local language, were trained in March 2016 to collect data. The actual data collection took place from April to June 2016 at Marabastad Mall in the CTMM. Prior to the completion of questionnaires, the RAs informed the respondents that their participation was voluntary. The RAs also informed the respondents about the purpose of the study and that they had the right to withdraw their participation if they did not feel comfortable whilst completing the questionnaires. After each questionnaire was completed, the RAs thanked the respondents for their participation. The population for this study was low-income workers working at or visiting Tshwane's Marabastad Mall. Initially, 1000 questionnaires were printed and participants were purposefully selected outside Marabastad Mall to complete them. The response rate was $87.4 \%$. Table 1 presents the biographical information. Most of the respondents were female $(n=351)$ and most respondents $(n=158)$ reported that they lived with six or more people in their household. Also, the majority $(n=489)$ of the respondents were not unionised. A total of 489 respondents' ages ranged from 25 to 44 years.

The questionnaire: The questionnaire comprised two sections; viz.: Section A collected biographical information and Section B comprised different scales. The nine items to measure employee engagement were taken from a scale developed by Schaufeli et al. (2002). Examples of questions are as follows: "At my work, I feel bursting with energy"; "My job inspires me"; and "I am proud of the work that I do". Nine items were taken from a job satisfaction scale (three items were supervision satisfaction, three items were co-worker satisfaction, and three items were rewards satisfaction) developed by Spector (1985). Some of the items are: "My supervisor shows little interest in the feelings of subordinates"; "I don't like the people I work with"; and "There are few rewards for those who work here". Nine items from the organisational commitment questions were adapted from Meyer and Allen's (1997) scale. Herewith are some of the items from the scale: "I really feel as if this organisation's problems are my own"; "Right now, staying with my organisation is a matter of necessity as much as a desire"; and "I think that people these days move from company to company too often". Nine items of talent management were adapted from the questionnaire developed by Van Hoek (2014). Examples of questions are as follows: "I receive relevant feedback on my performance"; "Acknowledgement for my work done is a motivating factor to remain in the organisation"; and "The organisation provides opportunities for further training and development". Nine items of the quality of work life were adapted from the scale developed by Walton (in Timossi, Pedroso, De Fransico \& Pilatti, 2008). Some of the items are: "It is difficult to concentrate on work because of home matters"; "My extra/fringe benefits (such as transport, doctor, dentist, cafeteria, etc.) are good"; and "I am satisfied with the number of hours I have to work weekly". The respondents evaluated job satisfaction, organisational commitment, talent management, and quality of work life on five-point scales where "1=strongly disagree", "2=disagree", " $3=$ =neutral", " $4=$ agree", and " $5=$ strongly agree". The respondents evaluated employee engagement on a six- 
point scale where " $0=$ never", " $1=$ almost never", " $2=$ rarely", “3=sometimes", " $4=$ often", " $5=$ very often", and "6=always".

Table1: Reliability Statistics

\begin{tabular}{lll}
\hline Cronbach's alpha & Cronbach's alpha based on standardised items & N of Items \\
\hline .90 & .90 & 46 \\
\hline
\end{tabular}

Validity and reliability: Prior to data collection, the questions' face validity was achieved by pre-testing the questionnaire on 20 respondents. Content validity was achieved by requesting research, industrial relations and HRM experts to review the questionnaire (Spector, 2012). From Table 1 it is clear that the Cronbach's alpha is displayed and since it is closer to 1 , it can be argued that the items used in the study are reliable (Bless, Higson-Smith \& Sithole, 2013; Maree, 2016).

\section{Results}

Descriptive statistics: The discussion below comprises the descriptive and inferential statistics. The data were coded in Microsoft Excel and was exported into SPSS version 24. As can be observed from the table, there were more females $(54.4 \%)$ than males $(45.3 \%)$ who participated in the study. The data also showed that $62.1 \%$ of employees were in full-time employment and $73.2 \%$ were not unionised.

Table 2: Biographical information

\begin{tabular}{llll}
\hline Variable & & Frequency & Percentage \\
\hline Gender & Male & 253 & $45.3 \%$ \\
& Female & 302 & $54.4 \%$ \\
Employment status & Employed full-time & 338 & $62.1 \%$ \\
& Employed part-time & 206 & $37.9 \%$ \\
Member of the union & 141 & $25.2 \%$ \\
& Yes & 406 & $73.2 \%$ \\
& No & 9 & $1.6 \%$ \\
\hline
\end{tabular}

Inferential statistics: In order to test biographical differences (i.e. gender, employment status, and member of the union), a T-test was conducted. The data showed that males were more engaged than their female counterparts. Also, Nienaber and Martins (2016) found that males were more engaged than female employees; part-time employees were slightly more engaged than full-time employees. As in the study conducted by Nienaber and Martins (2016), employees who were unionised were more engaged than the non-union members. Even though there were biographical differences, the effect sizes were very small because they were less than 0.06 (Pallant, 2016). Based on the study's results, H1A and H1B are supported and $\mathrm{H} 1 \mathrm{C}$ is not supported.

Table 3: Employee engagement: Biographical differences

\begin{tabular}{llllll}
\hline Variable & & Mean & T-statistic & P-value & Cohen d \\
\hline Gender & Male & 3.53 & 7.96 & 0.00 & 0.23 \\
Employment status & Female & 3.21 & & & \\
& Employed full-time & 3.72 & & & \\
Member of union & Employed part-time & 3.73 & 8.20 & 0.00 & -0.00 \\
& Yes & 3.61 & 2.29 & 0.02 & 0.23 \\
& No & 3.27 & & & \\
\hline
\end{tabular}

Level of significance $* \mathrm{P}<0.05$.

Before the linear regression analysis was conducted, certain assumptions were tested. The tolerance values were < than 0.10 and there was a variance inflation factor (VIF) which was $>$ than 10 . This seems to suggest that the assumptions of multicollinearity were not violated. The results were not surprising since there was no Pearson correlation between predictors that was 0.7 or above (Pallant, 2016). The Normal P-P Plot (i.e. not displayed in the paper) showed that the data centred around the solid line, moving straight from the bottom 
left to the upper right. This suggested that the linearity assumption was not violated (Pallant, 2016). It can be observed from Table 4 that the model was a good fit $(\mathrm{F}=64.65 ; \mathrm{p}<0.00)$ and the independent variables explained $42.7 \%$ of the variance in employee engagement.

Table 4: Predictors of employee engagement

\begin{tabular}{|c|c|c|c|c|c|c|}
\hline \multicolumn{7}{|c|}{$\begin{array}{l}R 2=0.427 \text { Dependent variable: Employee engagement } \\
\mathrm{F}=(64.563 ; \text { Sig= } .000 \mathrm{~b}) \mathrm{p}=0.00\end{array}$} \\
\hline \multirow{2}{*}{\multicolumn{2}{|c|}{ Model }} & \multicolumn{2}{|c|}{$\begin{array}{l}\text { Unstandardised } \\
\text { coefficients }\end{array}$} & \multirow{2}{*}{$\begin{array}{l}\begin{array}{l}\text { Standardised } \\
\text { coefficients }\end{array} \\
\text { Beta } \\
\end{array}$} & \multirow[b]{2}{*}{$\mathrm{t}$} & \multirow[b]{2}{*}{ Sig. } \\
\hline & & $\mathbf{B}$ & Std. error & & & \\
\hline \multirow[t]{7}{*}{1} & (Constant) & 2.087 & .232 & & 8.976 & .000 \\
\hline & QWL & -.217 & .045 & -.193 & -4.847 & .000 \\
\hline & $\mathrm{TR}$ & .275 & .066 & .193 & 4.162 & .000 \\
\hline & $\mathrm{TD}$ & .151 & .042 & .143 & 3.576 & .000 \\
\hline & JS & .432 & .067 & .284 & 6.426 & .000 \\
\hline & $\mathrm{CR}$ & -.236 & .051 & -.162 & -4.627 & .000 \\
\hline & OC & .073 & .047 & .060 & 1.544 & .123 \\
\hline
\end{tabular}

$\mathrm{QWL}=$ quality of work life, $\mathrm{TR}=$ talent recognition, $\mathrm{TD}=$ talent development; JS=job satisfaction, $\mathrm{CR}=\mathrm{co}$-worker relations, and $\mathrm{OC}=$ organisational commitment.

As can be observed from Table 4, five variables were statistically significant; with the exception of organisational commitment. Therefore $\mathrm{H} 2$ is not supported. Talent recognition, talent development, and job satisfaction had a positive effect on employee engagement. This is in line with the literature review (Halbesleben, 2010; Society of Human Resource Management (SHRM), 2107; Zikouridis, 2015). Based on the study results, H3, H5A, and H5B are supported. The data showed that quality of work life and co-worker relations had a negative effect (i.e. inverse relationship) on employee engagement. This may imply that when employee engagement increases the need for quality of work life and co-worker relations may decrease. Therefore, the researchers took Hair, Black, Babin and Anderson's (2014) advice that variables with negative Beta scores should not be analysed. This finding is in contrast with the literature review (Anitha, 2014; Slabbert et al., 2015). Based on the study results, $\mathrm{H} 4$ and $\mathrm{H} 6$ are not supported.

\section{Conclusion and Recommendations}

Based on the study results, it can be concluded that males and employees who were unionised were slightly more engaged and employees hired on a part-time basis were more engaged. It was also evident that their mean scores were below 4, suggesting that they were less engaged. These were the variables that have a positive effect on employee engagement (job satisfaction, talent development, and talent recognition). It can therefore be concluded that an increase in these variables will result in an increase in employee engagement. It can be argued that an increase in one point in employees' job satisfaction will result in .284 in employee engagement. Also, an increase in one point of talent recognition will result in .193 in employee engagement, and an increase in one point in talent development will result .143 in employee engagement. In light of these study outcomes, the following recommendations are made:

- Employers can maximise employee engagement by improving the job satisfaction of their employees. They should also know the low-income employees for who they are, not just what they do.

- If the talent of low-income employees is recognised and developed by their employers, they will be more engaged. It is therefore clear that employers must put in effort to liaise with these workers and give credit to high-potential employees.

The results of study provide the management of companies an incentive to develop strategies to effectively engage low-income workers. The effect of labour relations and quality of work life was not certain and reverse scored. Future studies may explore the reasons for this result. In terms of further research, it is recommended that similar research be conducted where a probability sampling technique is utilised. A longitudinal study can also be conducted. It is also recommended that researchers should use a mixedmethods research design because it produces rich and credible data (Bryman, 2012; Leedy \& Ormrod, 2015). 
Another recommendation for future research is to use confirmatory factor analysis (CFA) and a structural equation model (SEM) to develop a non-linear model for employee engagement. CFA will assist researchers to achieve discriminant validity (Ravand \& Baghaei, 2016; Tladinyane \& Van der Merwe, 2016) and SEM will assist researchers to determine the direct and indirect relationship between independent variables (i.e. job satisfaction, talent management, etc.) and employee engagement. Since the authors did not explore biographical significant difference in the present study, they recommend that in the future researchers should undertake such a study. The study has implications for policymakers that employees earning between R1 000.00 and R10 000.00 were less engaged and committed and their job satisfaction levels were low. The implication for managers is that they must be aware that development and recognition of employees and job satisfaction predict employee engagement and quality of work life and employee relations did not predict employee engagement.

This study had different limitations. It used a cross-sectional and non-probability sampling technique. In terms of the latter, the results cannot be generalised to all low-income workers. The authors had to use their research account; hence the non-probability sampling technique was deemed the most cost-effective option. The other limitation was the research instrument. Unlike other employee engagement research in South Africa (see Nienaber \& Martins, 2016, p.66), it did not cover all the industries in which low-income workers are hired. Since exploratory factor analysis (EFA) was used in the present study, some items did not load on the original factors or variables (Babbie, 2013). In conclusion, if employees truly are an organisation's best asset, employers should be more compassionate towards lower-income workers and focus more attention to their needs. This could be an opportunity to transform their employees' work experiences to be more fulfilling and meaningful. Every interaction with an employee has the potential to influence his or her engagement and inspire discretionary effort. This study has contributed to a better understanding of what is important regarding employee engagement of low-income workers in the CTMM in South Africa.

\section{Acknowledgements}

The authors are grateful to Professor Stuart Carr from Massey University for doing exploratory data analysis and re-coding the variables that were used in this study to conduct multiple linear regression. The authors also express their sincere thanks Department of Higher Education and Training, through the Research and Innovation Directorate at Tshwane University of Technology, for sponsoring Dr Dachapalli and Mrs Ragadu to go to New Zealand to do preliminary statistical analysis (i.e. recoding of data). Dr Maleka conceptualised the study, wrote the methodology, results, abstract and discussion. Dr Dachapalli and Prof. Schultz wrote the theoretical section and Dr Van Hoek and Mrs Ragadu wrote the introduction.

\section{References}

Albdour, A. A. \& Altarawneh, I. I. (2014). Employee engagement and organisational commitment: Evidence from Jordan. International Journal of Business, 19(2), 192-212.

Albert, S. L., Baker, A. B., Gruman, J. A., Macey, W. H. \& Saks, A. M. (2015). Employee engagement, human resource management practices and competitive advantage: A competitive edge. Journal of Organisational Effectiveness: People and Performance, 2(1), 7-35.

Alqarni, S. A. Y. (2016). Quality of work life as a predictor of work engagement among the teaching faculty at King Abdulaziz University. International Journal of Humanities and Social Science, 6(8), 118-135.

Anitha, J. (2014). Determinants of employee engagement and their impact on employee performance. International Journal of Productivity and Performance Management, 63(3), 308-323.

Ariani, D. W. (2015). Relationship with supervisor and co-workers, psychological condition and employee engagement in the workplace. Journal of Business and Management, 4(3), 34-47.

Babbie, E. (2013). The Practice of Social Research (13th ed.). Belmont, CA: Wadsworth Cengage Learning.

Beukes, I. \& Botha, E. (2013). Organizational commitment, work engagement and meaning of work of nursing staff in hospitals. South African Journal of Industrial Psychology, 39(2), 1-10.

Bless, L., Higson-Smith, C. \& Sithole, S. L. (2013). Fundamentals of Social Research: An African Perspective. Claremont:Juta.

Bryman, A. (2012). Social Research Methods. New York, NY: Oxford University Press.

Carr, S. C., Maleka, M. J., Meyer, I., Barry, M. L., Parker, J. \& Haar, J. (2017). Sustainable livelihood in two diverse economies: From working poverty to living wages. (In press.) 
Chandarot, K. \& Dannet, L. (2009). Living Wage Survey for Cambodia's Garment Industry. Phnom Penh, Cambodia: Cambodian Institute of Development Study (CIDS).

Cohen, A. (2007). Commitment before and after: An evaluation and reconceptualization of organizational commitment. Human Resource Management Review, 17, 336-354.

Dessler, G. (1984). Personnel Management: Modern Concepts \&Techniques (3rd ed.). Reston, VA: Reston Publishing.

Galea, C., Houkes, I. \& De Rijk, A. (2014). An insider's point of view: How a system of flexible working hours helps employees to strike a proper balance between work and personal life. The International Journal of Human Resource Management, 25(8), 1090-1111.

Gallup. (2013). State of the Global Workplace. Available at: http://www.gallup.com/topic/state_of_the_ global_workplace_2013.aspx.

Garg, A. \& Kumar, V. (2012). A study of employee engagement in the pharmaceutical sector. International Journal of Research in IT and Management, 2(5), 85-98.

Ghosh, P. A., Rai, A. \& Chauhan, R. G. (2016). Rewards and recognition to engage private bank employees: Exploring the obligation dimension. Management Research Review, 39(2), 1738-1751.

Hair, J. F., Black, B. J., Babin, B. J. \& Anderson, R. E. (2014). Multivariate Data Analysis (7th ed.). Harlow: Pearson Education Limited.

Halbesleben, J. R. B. (2010). A meta-analysis of work engagement: Relationship between burnout, demands, resources, and consequences. In A. B. Bakker \& M. P. Leiter (Eds.), Work Engagement: A Handbook of Essential Theory and Research (pp. 102-117). New York, NY: Psychology Press.

Hewitt, A. (2015). 2015 Trends in Global Employee Engagement. Available at: http://www.aon.com/attachments/human-capital-consulting/2015-Trends-in-Global-EmployeeEngagement-Report.pdf.

Hughes, J. L. \& Hog, E. (2008). Talent management: A strategy for improving employee recruitment, retention and engagement within hospitality organizations. Journal of Contemporary Hospitality Management, 20(7), 743-747.

Islam, M. B. (2012). Factors affecting the quality of work life: An analysis one employee of private limited companies in Bangladesh. Global Journal of Business and Management Research, 12(8), 1-10.

Jackson, L. T. B., Rothmann, S. \& Van de Vijver, A. J. R. (2006). A model of work-related well-being for educators in South Africa. Stress and Health, 22(4), 263-274.

Janse van Rensburg, Y., Boonzaier, B. \& Boonzaier, M. 2013. The job demands-resources model of work engagement in South African call centres. SA Journal of Human Resource Management, 11(1), Art. \#484. http://dx.doi.org/10.4102/ sajhrm.v11i1.484.

Karanika-Murray, M., Duncan, M., Halley, M., Pontes, M. \& Griffiths, D. (2015). Organizational identification, work engagement, and job satisfaction. Journal of Managerial Psychology, 30(8), 1019-1033.

Leedy, P. A. \& Ormrod, J. E. (2015). Practical Research: Planning and Design (4th ed.). Boston, MA: Pearson Education.

Locke, E. A. (1976). The nature and causes of job satisfaction. In M. D. Dunnette (Ed.), Handbook of Industrial and Organisational Psychology (pp. 1297-1349). Chicago, IL: Rand McNally.

Lu, L., Lu, A. C. C., Gursoy, D. \& Neale, N. (2016). Work engagement, job satisfaction, and turnover intentions: A comparison between supervisors and line-level employees. International Journal of Contemporary Hospitality Management, 28(5), 737-761.

Madlock, P. E. \& Booth-Butterfield, M. (2012). The influence of relational maintenance strategies among coworkers. International Journal of Business Communication, 49(1), 21-47.

Makhoa, I. M. (2016). Assessing satisfaction with change management process and work engagement levels of engineers of engineers in an electricity supplier. MBA. North-West University, Potchefstroom.

Makhubu, N. (2016). Tuks reaches deal with the in sourcing. Pretoria News, p. 1.

Maleka, M. J. (2017). Exploring the relationship between a living wage and human resources outcomes: evidence from Tshwane Marabastad Mall. In GBATA Conference Proceedings.

Maree, K. (2016). First Steps in Research (2nd ed.). Pretoria: Van Schaik.

Markos, S. \& Sridevi, M. S. (2010). Employee engagement: The key to improving performance. International Journal of Business and Management, 5(12), 89-96.

Memari, N., Mahdieh, O. \& Marnani A. B. (2013). The impact of Organizational Commitment on Employees Job Performance. A study of Meli bank. Interdisciplinary Journal of Contemporary Research in Business, 5(5), 164-170. 
Mensah, J. K. (2015). A "coalesced framework" of talent management and employee performance. International Journal of Productivity and Performance Management, 64(4), 544-566.

Meyer, J. P. \& Allen, N. J. (1991). A three-component conceptualization of organizational commitment. Human Resource Management Review, 1, 61. doi:10.1016/1053-4822(91)90011-Z.

Meyer, J. P. \& Allen, N. J. (1997). Commitment in the Workplace. Thousand Oaks, CA: Sage Publications.

Moshoeu, A. N. \& Geldenhuys, D. J. (2015). Job insecurity, organisational commitment and work engagement among staff in an open distance learning institution. Southern African Business Review, 19(1), 22-43.

Nienaber, H. \& Martins, N. (2016). Employee Engagement in a South African Context. Randburg: KR Publishing.

Olivier, A. \& Page, T. (2017). Rewriting the Rules of the Digital Age: 2017 Human Capital Trends Report for South Africa. London: Deloitte University Press.

Pallant, J. (2016). SPSS Survival Manual. A Step-by-step Guide to Data Analysis Using IBM SPSS (6th ed.). Crows Nest: Allen \& Unwin.

Ravand, H. \&Baghaei, P. (2016). Partial least square structural equation using R. Practical Assessment, Research and Evaluation, 21(11), 1-16.

Robyn, A. \& Du Preez, R. (2013.) Intention to quit amongst Generation Y academics in higher education. South African Journal of Industrial Psychology, 39(1), 111-121.

Rothmann, S. \& Rothmann, S. (2010). Factors associated with employee engagement in South Africa. South African Journal of Industrial Psychology, 36(2), Art. \#925. doi:10.4102/sajip.v36i2.925.

Schaufeli, W. B. \& Bakker, A. B. (2003). Test manual for the Utrecht Work Engagement Scale. Unpublished manuscript. The Netherlands: Utrecht University.

Schaufeli, W. B., Salanova, M., González-Romá, V. \& Bakker, A. B. (2002). The measurement of engagement and burnout: A two-sample confirmatory factor analytic approach. Journal of Happiness Studies, 3, 71-92.

Slabbert, J. A., Parker, A. J. \& Farrel, D. V. (2015). Employment Relations Management: Back to Basics. A South African Perspective. Durban: LexisNexis.

Society of Human Resource Management (SHRM). (2017). Employee Job Satisfaction and Engagement: The Doors of Opportunity are Open. Available at: https://www.shrm.org/hr-today/trends-andforecasting/research-and-surveys/pages/20170-job-satisfaction-and-engagement-doors-ofopportunity-are-open.aspx.

Spector, P. (1985). Measurement of human service staff satisfaction: Development of job satisfaction survey. American Journal of Community Psychology, 13, 693-713.

Spector, P. E. (2012). Industrial and Organizational Psychology: Research and Practice (6th ed.). USA: John Wiley\& Sons.

Timossi, L. D., Pedroso, B., De Fransico, A. C. \& Pilatti, L. A. (2008). Evaluation of quality of work life: An adaptation of the Walton's QWL Model. Paper presented at the XIV International Conference on Industrial Engineering and Operations Management (ICIEOM), Rio de Janeiro, 13-16 October 2008.

Tladinyane, R. \& Van der Merwe, M. (2016). Career adaptability and employee engagement of adults employed in an insurance company: An exploratory study. Journal of Human Resource Management, $14(1), 1-9$.

Van Hoek, C. E. (2014). A Competitive Talent Management Strategy for a Natural Resource Mining Company in Selected Countries in Africa. Unpublished D-Tech thesis. Tshwane University of Technology, Pretoria.

Zikouridis, F. (2015). Employee Engagement and Job Satisfaction: A Research between Their Relationship in a Real Context. Unpublished doctoral thesis. International Hellenic University, Greece. 